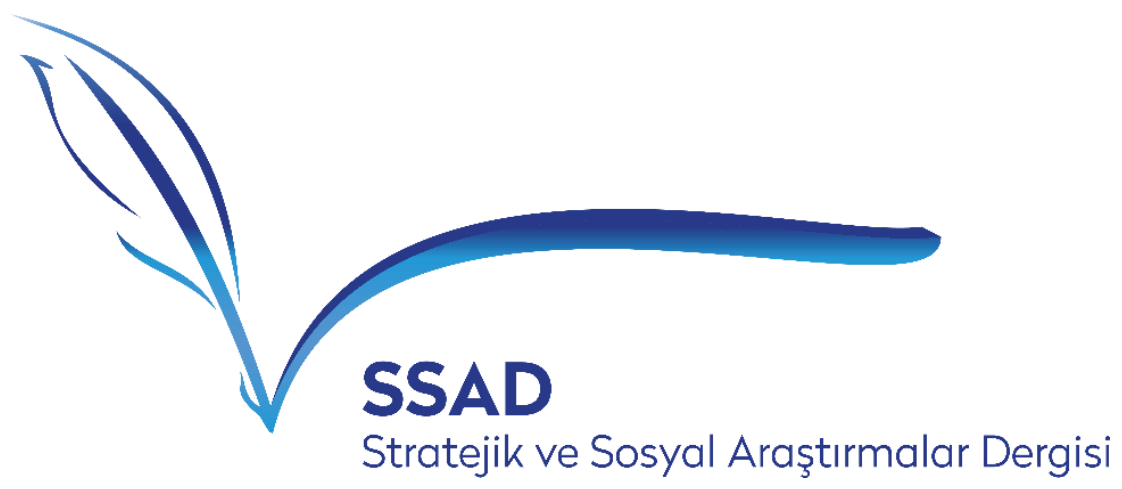

ISSN : $2587-2621$

Volume 3 Issue 2, July 2019

ORCID ID: 0000-0002-8415-8002

Makale Gönderim Tarihi: 30.06.2019

Makale Kabul Tarihi: 17.07.2019

\title{
KENT YAŞAMI MEMNUNIYETİ, STRESLE BAŞA ÇIKMA VE YAŞAM DOYUMU İLIŞKİSİ: İSTANBUL ÖRNEĞİ
}

\section{The Relationship Between Urban Life Satisfaction, Stress and Life Satisfaction: The Case of Istanbul}

\author{
Ferda Şule KAYA \\ Dr. $\ddot{O} \breve{g r}$. $\ddot{U}$ yesi \\ Demiroğlu Bilim Üniversitesi, Fen-Edebiyat Fakültesi, Psikoloji Bölümü \\ kaya.s2565@gmail.com
}

Öz: Bu çalışma; İstanbul'da ikamet edenlerin şehirle ilgili memnuniyet düzeyi ile yaşam doyumu ve stres düzeyleri arasındaki ilişki incelenmiştir.

Bu araştırmanın evrenini İstanbul'da ikamet eden yetişkinler oluşturmaktadır. Örnekleminin İstanbul popülasyonunu temsil etmesi için TÜiK 2018 verilerine göre İstanbul eğitimli ortalamasını temsil eden semtlerde yaşayan (169 kişi), ortalamanın altındaki semtlerde yaşayan (103 kişi) ve ortalamanın üstündeki semtlerde yaşayan (160 kişi) toplam 434 gönüllü katılımcı oluşturmuştur.

Araştırmada kişisel bilgi formu ve 3 ölçek kullanılmıştır. Kişisel bilgi formu; yaş, cinsiyet, eğitim düzeyi, medeni durumu, İstanbul'u vazgeçilmez yapan özellikler nelerdir sorularından oluşmaktadır. Araştırmada ayrıca; Tatar vd. (2017) tarafindan geliştirilen "Kent Yaşamından Memnuniyet Ölçeğì", Kaba vd. (2018) tarafindan geliştirilen "Yetişkin Yaşam Doyum Ölçeği", Moos (1993) tarafından geliştirilen "Stresle Başa Çıkma Yöntemleri Ölçeğì" kullanılmıștır.

Araştırma bulgularında; kent memnuniyeti, yaşam doyumu ve stresle başa çıkma açısından anlamlı bir ilişki bulunmuştur. İstanbul, market, kafe, eğitim kurumları konusunda memnun olunan bir şehir olarak görülürken, gürültü kirliliği, ev- kira fiyatlarının yüksek olması, insan yoğunluğu, hava kirliliği, çarpık kentleşme açılarından memnun olunmayan bir şehir olarak ifade edilmiştir. İstanbul'u vazgeçilmez kılan durum olarak tarihi özelliği ifade edilmiştir. 
Sonuç olarak; İstanbul'un kültür kenti değil, AVM kenti olduğu, eğitim kurumlarının niceliksel arttı̆̆ fakat kültürel etkinliklerin azlığı sebebi ile niteliksel artmadığı ve gürültü ve hava kirliliğine sahip bir arada yaşamaktan zorlanan insan kalabalığına sahip bir şehir olarak algılandığı bulgusuna ulaşılmıştır.

Anahtar Kelimeler: Şehir, Şehir Memnuniyeti, Stres, Yaşam Doyumu.

\begin{abstract}
In this study, the relationship between city satisfaction level and life satisfaction and stress levels of the residents of Istanbul was examined.

The population of this study consists of adults residing in Istanbul. In order to represent the Istanbul population of the sample, according to TurkStat 2018 data, a total of 434 participants living in different districts were constituted. Participants were in three different education group which are living in different districts in the Istanbul average of education (169 people), living in districts below the Istanbul average of education (103 people) and living in districts above the Istanbul average of education (160 persons). People participated in the study on a voluntary basis.

Personal information form and 3 scales were used in the study. Personal information form consist on; age, gender, education level, marital status, and what makes Istanbul indispensable. Also in the research "Development of A Urban Life Satisfaction Scale" which developed by Tatar et al, (2017)" Adults Life Satisfaction Scale" which developed by Kaba et al.(2018) and "Emotional Reactivity Scale" which developed by Moos 1993 were used.

Research findings points considerable relations between city satisfaction, satisfaction of life and emotional reactivity , fighting with stress. İt is also discovered İstanbul is not described as a cultural rich city but more likely rich for the quantitiy of shopping malls. Educational İnstututions are much more in numbers but not in good quality due to absence of cultural activities. City is perceived as a place where crowded people forced to live together in polution and rumble.
\end{abstract}

Keywords: City, City Satisfaction, Stress, Life Satisfaction

\title{
1. Giriş
}

Şehir kavramı, insanlık tarihi kadar eskiye dayanan bir geçmişe sahiptir. Kentler, tarihi proses içinde medeniyetlerin oluşumunda rol oynayan, büyümesine ve gelişmesine katk1 sağlayan alanlar olmuşlardır.

İnsanoğlunun yerleşik hayata geçmesi ile başlayan kentleşme olgusu, günümüzde kalabalık ve yan komşusunu tanımayan ve bireyi yalnızlığa iten olguya dönüşebilmiştir. Kentleşme olgusuna, tarihsel süreç açısından baktığımızda verimli arazilerin olduğu Mezopotamya'da M.Ö. 300-5000 yıllarında başlamış bir süreç olarak tanımlanmaktadır. Burada ihtiyaçtan fazla üretilen tarım ürünleri yine ihtiyaçtan fazla üretilen diğer bölgelerdeki tarım ürünlerinin değiş tokuşu ile başlayan insanların bir arada yaşama organizasyonları olarak ortaya çıkmıştır (Benovolo, 1995).

Günümüzde ise kentleşme, sanayi devrimi ile başlayan ve bireyin eğitim, sağlık, iş olanakları ve barınma gibi temel ihtiyaçlarının en üst düzeyde karşılandığ karmaşık fakat mükemmel yapılar olarak tanımlanmaktadır (Tatlıdil, 1994). Bu organizasyonlar bireyler tarafindan oluşturulduğuna göre mükemmele ulaşmak iyi yetişmiş insan malzemesi ile mümkün olabilmektedir. Her çevreden ve her kültürden kaliteli insan gruplarını bir arada toplayan organizasyonlara kucak açsa da diğer taraftan bir arada yaşamakta zorlanan farklı grupları da bir araya getiren karmaşık sistemlere dönüşmesine sebep olabilmiştir. Bu durum ise kenti güvenlik ve bir arada yaşama sorunları sebebi ile yaşanması zor ve stresli alanlar olarak tanımlanır hale dönüştürmüştür. Bu çalışma bu sebeplerle kent memnuniyetini incelerken, bireyin yaşam memnuniyeti ve stresle başa çıkma davranışlarını da incelemeyi hedeflemiştir.

George Simmel (1903) Metropolis ve Modern Yaşam (Metropolis and Modern Life 1903) konulu araştırmasında şehirde yaşayan bireyin zihnindeki algıları incelemiş ve şehir hayatını, bireyin hayata bakışııı, izlenimlerini ve imajlarını tanımlamıştır. Bireyin zihnindeki kent yaşamından gelen yoğun uyaranlar sebebi ile duyarsızlaştığını ve bu yoğun uyaran bombardımanından bu şekilde korunduğunu ifade etmektedir. Şehir hayatı küçük yerleşim yerlerindeki sakin ve huzurlu ortamdan uzaktır. Şehir hayatında yoğun ve çok yönlü uyaranlar 
karşısında bilişsel ve duyusal anlamda gelişen birey diğer taraftan sürekli değişim gösteren imgeler karşısında da duyarsızlaşarak kendisini koruma altına alabilmektedir Simmel, kentlerde yaşayanların zaman içinde şehir karmaşasının bir parçası olduklarını ve birbirlerinden uzaklaştıklarını ifade etmektedir. Bu durum zamanla bireyin kendisini, yalnız ve kimsesiz hisseden bireyler topluluğuna dönüş̧ürdüğünü ve sosyologlar açısından incelenen bir konuya dönüşmüştür. Şehir yaşamının bireylerin hayatına etkisi, hangi durumlarda olumlu olduğu, hangi durumlarda zarar verebildiğini veya bir arada yaşamanın olumlu tarafları gibi çeşitli araştırmalarla açıklanmıştır.

Wirth (2002) ise şehir kavramını sosyal düzen kapsamıyla ilişkisi olmayan, nüfus, yoğunluk ve heterojenlik gibi üç özellikte tanımlamıştır. Bir başka ifade ile şehirde düzen vardır, çeşitli eğitim ve kültür düzeyinden insanlar bir arada yaşamaktadır ve kalabalıktır.

Gelişmiş veya uzun yıllar varlığını sürdüren şehirler bireyler üzerinde imaj oluşturmaktadır. Şehirler, sahip oldukları mimari, kültürel ve tarihsel dokusu ile bir kimliğe sahip olmaktadırlar. $\mathrm{Bu}$ durum o şehirde yaşayanların algısını, yaşam şeklini, giyim kuşam ve davranış biçimlerini etkilemektedir. Sahip oldukları özellikleri ile sanayi şehri, liman şehri, kültür şehri gibi isimler alabildiği gibi bireylerde uyandırdığı duygu ve düşüncelerle kişilik sahibi yapılara dönüşebilmektedir (Engez, 2007).

Şehirler içinde yaşayan bireyler ile sürekli etkileşim halindedirler. Bu durum birey ile şehir arasında bağların oluşumuna sebep olur. Bireyin, yaşadığ 1 şehri nasıl algıladığı, hangi bölgesinde ve ne amaçla zamanını geçirdiği ve kurduğu bağın derecesi, kendisini o şehre ait hissetmesi üzerinde etkilidir. Bağların kuvvetli olduğu durumda sosyal kimliğinde kendisini birinci dereceden yaşadığ duyguları ve değerleri tarafından belirlenen ve kişinin kimliğini oluşturan karmaşık bir yap1 olarak tanımlamaktadır. Bilgin (2011)'de kent kimliğinin insanların o kente yükledikleri anlam ile oluşacağını ifade eder. Burada bireyler kentin kendilerine verdiği fiziksel ve duygusal uyarılarla, o kente iliş̧in algı geliştirirler. Bu durum da "benlik-kimlik" etkileşiminden oluşan zihinsel yapıdır ve kent kimliği olarak da tanımlanmaktadır. Kentler fiziksel özellikleri ve yaşam biçimleri ile bireyler üzerinde etki oluşturur, bu etki bireylerin zihninde yoğurularak bireyler tarafindan oluşturulan ve bu kente atfedilen kimliğe dönüşür. Kent kimliği birey-çevre etkileşiminin ürünüdür.

Stres kavramı ilk olarak Selye (1956) tarafından bireyin dış uyaranlara karşı gösterdiği düşünsel, duygusal ve davranışsal tepkiler olarak tanımlamıştır. Selye ayrıca bireye içeriden ve dışarıdan gelen uyaranların fazla olması durumunda zorlandığını ve çeşitli savunma mekanizmalarına baş vurduğu ifade edilmektedir. Stres, yaşam sonucu ortaya çıkan normal ve gerekli bir süreçtir (Dyce, 1973). Bireylerin uyaranlara fazla maruz kalması aşırı uyarılmış olarak tanımlanır. Aşırı uyarılmışlık, düzeyine göre olumlu ve olumsuz yönleri ile açıklanmaktadır. Olumlu yönü bireyin gelişimini ve çok yönlü düşünmesini desteklemek olarak ifade edilir. Olumsuz yönü ise bireyin psikolojik ve fiziki sınırlarını tehdit edebilecek düzeyde olmasıdır (Baltaş ve Baltaş 2002). Çevrenin hiç stres yaratmaması bireyin kendisini monoton ve sıkıcı bir ortamda algılamasına sebep olur. Böyle bir ortamda huzur vardır fakat bireyler genellikle her gün aynı şeyleri yaşamaktadırlar.

Rapoport (1977) çevreyi davranışsal, algısal, işlevsel ve coğrafi olarak dört grupta tanımlamaktadır. Davranışsal Çevre, birey grup etkileşimini, Algısal Çevre, bireyin çevreyi algılaması ve çevre ile etkileşimi sonucunda zihninde oluşan çevre sistemini, İşlevsel Çevre, bireyin ve toplumun ürettiği mimari mekanları ve Coğrafi çevre ise bireyin ve grupların içinde bulundukları doğal çevredir. Bu çerçevede çalışmamız algısal çevre alt başlığını incelemektedir. İstanbul'da yaşayanlar İstanbul'u memnuniyet düzeyi olarak nasıl algıladığı araştırılmaktadır. Ayrıca şehir memnuniyeti, yaşam memnuniyeti ve stres arasındaki ilişkilere bakılmıştır. Bireyin algısal çevresi, bireyi zorlayacak düzeyde uyarıcı veya bireyin ihtiyaçlarına cevap veremeyecek düzeyde ise olumsuz stres oluşmaktadır (Hançerlioğlu 2002) Kentin birey üzerinde olumsuz stres 
yaratmaması önemlidir. Memnun olduğu özelliklerin fazla olduğu ve olumsuz stres yaratmayan şehir bireyin yaşam doyumunu olumlu yönde etkileyecektir.

Şehirleşme veya Kentlileşme kavramı, kent yaşamına uyum sağlamak demektir. İnsan eliyle yapılmış olan bu yerleşim yerleri, yıllar içinde biriktirdiği bilgi ve kültür değerleri ile doğal çevrenin önüne geçebilmiştir. Bu anlamda kentli olmak, kentin sahip olduğu bilgi ve kültür değerlerine sahip olmak anlamına gelmektedir. Kent kimliği denildiği zaman ise sahip olduğu doğal, tarihi, kültürel özellikler açısından öne çıkan ve kendisine yakıştırılan tanımlamalardır (Lynch, 1996). Önemli sayılan dünya şehirlerine baktığımızda; Paris Eiffel kulesi, Venedik gondollar veya Floransa sanat, Paris kültür, Vatikan din şehri olarak tanımlanmaktadır. Bu anlamda İstanbul boğazı, tarihi özellikleri, kültürel etkinlikleri ve dini özellikleri ile bir metropol şehir olarak tanımlanmaktadır. İstanbul'un simgesi olarak ise camiler, martılar, galata kulesi gösterilebilmektedir (Çizgen, 1994).

Şehir kimliği ise; bireyin yaşadığı şehirle nasıl bir etkileşim içinde olduğu ve şehirdeki mekanlarla etkileşimi ve bireyin deneyim zenginliğinden ortaya çıkan semboller bütünüdür (Bell, Fisher ve Loomis, 1978; Lalli, 1992).

Şehirdeki yaşam alanlarının bireyin ihtiyaçları ile doğru orantılı olması bireyin memnuniyetine, şehri algılamasına ve bağ kurmasına sebep olurken, tersi durum bireylerin şehre zarar veren, saldırganlık ve şehir güvenliğini tehdit etme eğilimlerini arttırabilmektedir (Berkowitz, 1989). Çalışmamız bu sebeplerle İstanbul'da yaşayanların stresle başa çıkma düzeylerini de incelenmiştir.

Yaşam doyumu, bireyin ihtiyaçlarına cevap veren organizasyonlarla mümkündür. Şehrin ölçülebilir mekânsal, fiziksel ve toplumsal bileşenleri ve bireylerin bu bileşenleri nasıl algıladığı, yaşam doyumunu ve algısını etkilemektedir (Van Kamp vd., 2003). Bu bileşenleri somut, nesnel veriler üzerinden değerlendirdiğimiz durumda yer altı hizmetlerinin kalitesi, hava ve suyun temizliği, sanatsal ve kültürel etkinliğin düzeyi, eğitim ve sağlı imkanları memnuniyetin nesnel bileşenleridir (Liu, 1976).

Yaşam doyumu bireylerin sahip olmak istedikleri ile sahip olduklarını düşündükleri durumlar arasındaki paralelliğe işaret etmektedir. Öznel veya sübjektif bir durum olarak tanımlanmaktadır Öznel iyi oluşun duygusal bileşenini olumlu ve olumsuz duygular, bilişsel bileşenini ise yaşam doyumu oluşturmaktadır (Diener, 1984, 1994; Pavot ve Diener, 1993; Pavot, Diener, Colvin ve Sandvik, 1991). Yaşam doyumu beklentilere ulaşmak olarak tanımlandığına göre; bireyin içinde bulunduğu koşullara göre beklenti geliştirmesi bilişsel bileşenin doğru analiz edilmesi ile mümkündür (Özer ve Karabulut, 2003). Bir başka ifade ile bireyin istekleri ve elde ettikleri birbiri ile ne kadar uyumlu ise yaşam doyumu o kadar güçlü olacaktır (Diener, Oishi ve Lucas, 2003).

Günümüzde şehirlerdeki özellikle küreselleşme ile başlayan nüfus yoğunluğu, iktisadi alandaki liberalleşme, artan iş yükü, işsizlik ve lüks hayata ulaşma gayreti bireyin yıpranmasına ve kendisini baskı altında hissetmesine neden olmaktadır. Bu sebeplerle stres "modern toplumun hastalığı" olarak tanımlanmaktadır (Sabuncuoğlu \& Tüz, 1998). Değişim ve gelişim modern hayatın bir parçasıdır. Bireyin bu değişime uyum sağlaması, çok çalışması ile mümkündür. Burada stresi ortadan kaldırmak değil etkili kullanmak önemlidir. Stresle başa çıkmak olarak tanımlanan durum, kişinin problem çözme becerilerini arttırması ve güçlendirmesi ile mümkündür. Bir diğer ifade ile bireyin gelişimini desteklemektir (Lazarus ve Folkman, 1984).

Bireylerin beklentilerinin ve ihtiyaçlarının artması ile bugün şehirler çok boyutlu alanlara dönüşmüştür. Şehirler artık; sanayi ve ticaret odaları, sivil toplum örgütleri, medya kuruluşları, eğitim ve sağlık sektöründeki gelişmişlikleri ile çok-aktörlü yönetimlerden söz etmektedir. Bu sebeplerle; bireyi doğru anlayabilen, bireyin ihtiyaçlarına ve beklentilerine karşılık veren yapılar olarak tanımlanmaktadır. Şehri oluşturan kurumlar bu durumu sağladığı sürece varlığını devam ettirebilmektedir (Kaypak, 2013). 
Küreselleşme ve hızla nüfusun artması ve nüfusun şehirlere doğru hareketlilik kazanması gökdelenlerin şehirlere girişini arttırmıştır. Daha önce tarihi ve kutsal binaların yüksek ve görünür olduğu kentler, gökdelenlerin gölgesinde ve doğadan uzak yaşam alanlarına yerini bırakmıştır. Bireylerin, şehirlerde yaşamalarını kolaylaştırmak adına hızla çoğalan gökdelen yapıların büyüklüğ̈̈, enerji tüketimi, alt yapı ve şehir ışılarına olumsuz etkisi, çevre sorunları ile bireye ve kent kimliğine ne kadar fayda sağladığı sorgulanır hale gelmiştir (Duru, 2001) Bu durum Bookchin (1999) tarafından kentsiz kentleşme olarak tanımlanmaktadır. Kenti simgeleyen tarihi, sanatsal, etik ve dini özelliklerin gökdelenlerin gölgesinde kaybolduğunu ve yerini ekonomik ve küresel güçlerin sembolü olan gökdelenlere bırakıldığını ifade etmektedir. Bu durum bir arada yaşamaktan ve bir arada gelişmekten hız alan kentlileşmenin yerini bir arada güç ve para kazanmaya bıraktığını düşündürebilir.

İstanbul büyük bir tarihinin olmasının yanı sıra sosyal yaşamıyla, ticaretin kalbi sayılacak konumuyla da göçlere açık cazip bir merkez haline gelmiştir. 2017 TÜİK verilerine göre nüfusu 15.029.231 olarak açıklanmıştır.

İstanbul; yer yer geleneksel dokusunun korunduğu ve dünyanın en eski şehirlerinden biridir. Tarihsel süreç içinde birçok medeniyete ev sahipliği yapmıştır. İstanbul; 330-395 yılları arasında Roma İmparatorluğu, 395-1204 ile 1261-1453 yılları arasında Bizans İmparatorluğu, 1204-1261 arasında Latin İmparatorluğu ve son olarak 1453-1922 yılları arasında Osmanlı İmparatorluğu'na başkentlik yapmış bir şehirdir. İstanbul, dünya ve ülke tarihi açısından önemli bir dünya şehridir.

İstanbul'da yaşayan bireylerin sosyal ve psikolojik açıdan algılarının belirlenmesi, o kent yöneticilerine, şehir sakinlerinin sorunlarına ve çözümüne yönelik bilgiler vermesi şehrin memnuniyetini ve stresini doğru kullanmak açısından önemlidir.

Çalışmanın ana problemi şehir memnuniyet düzeyi, yaşam doyumu ve stresle başa çıkma ilişkisini incelemektedir.

Alt problemleri ise;

1. İstanbul'da yaşayan bireylerin İstanbul'a ait memnun olduğu ve memnun olmadığı özellikler nelerdir?

2. Cinsiyet, medeni durum ve mensup oldukları yaş yaşam memnuniyetini etkilemekte midir?

3. İstanbul'u vazgeçilmez yapan özellikleri ile kent memnuniyeti, yaşam doyumu ve stresle başa çıkma açısından bir ilişki var mıdır?

\section{YÖNTEM}

\subsection{Araştırmanın amacı}

$\mathrm{Bu}$ çalışma İstanbul sakinlerinin şehir memnuniyeti düzeyi ile yaşam doyumu ve stres düzeyleri arasındaki ilişkiyi incelemeyi amaçlamaktadır.

\subsection{Veri toplama araçları}

Kişisel Bilgi Formu; yaş, cinsiyet, eğitim düzeyi, kaç yıldır İstanbul'da ikamet ettiği, medeni durumu, yaşadığı semtten memnun olup olmadığı, toplu taşıma kullanım sıklığı, imkân olsa başka şehirde yaşamak isteyip istemediği, İstanbul'u vazgeçilmez yapan nedir sorularından oluşmaktadır.

Kent Yaşamı Memnuniyeti; kentin fiziki koşullarından, kültürü ve tarihsel geçmişinden, sunduğu imkanlardan, idari yönetiminden ne kadar memnun olduğunu belirleyen sorulardan oluşan bir ölçektir. Tatar, Özüdoğru, Uysal ve Uygur (2017) tarafindan geliştirilen "Kent Yaşamından Memnuniyet Ölçeği” 50 maddeden oluşmuştur ve cevaplar 5'li Likert ile ölçülmüştür. 
Tüm maddeler için madde-ölçek toplam puan korelasyonu değerleri 0,34 ile 0,62 arasında gerçekleşmiştir. Formun 50 madde ile Cronbach Alfa iç tutarlılık katsayısı 0,95 olarak gerçekleşmiştir. Formun iki yarım test güvenirlik analizi sonuçlarına göre ise birinci yarı için iç tutarlılık katsayısı 0,91, ikinci yarı için iç tutarlı1ık katsayısı 0,92, iki yarı arası korelasyon katsayıs1 0,75, eşit iki yarı için Sperman-Brown ve Guttman iki yarım test katsayıları ise 0,86 olarak gerçekleşmiştir. Temel bileşenler ve varimax döndürme analiz yöntemleri ile yapılan faktör analizi sonucuna göre tek faktörlü yapı ile toplam varyansın 0,29 'u açıklanmaktadır. Farklı döndürme ve farklı faktör yapıları test edilmiş ancak öz değer dikkate alındığında bu yöntemlerin her birinde tek faktörlü yapının belirgin olarak öne çıktığı görülmüştür.

Yetişkin Yaşam Doyum Ölçeği ise Kaba, Erol ve Güç (2018) tarafından geliştirilmiştir. Ölçek; genel yaşam doyumu, ilişki doyumu, benlik doyumu, sosyal çevre doyumu ve iş doyumu olmak üzere beş alt boyuttan oluşmaktadır. Ölçekten alınan yüksek puan kişinin kendi yaşamı ile ilgili olumlu düşünceye sahip olduğunu belirtmektedir. Yetişkin Yaşam Doyumu Ölçeği (YYDÖ) 21 maddeden oluşmakta ve 5'li Likert ile ölçülmektedir.

Ölçeğin yapı geçerliği açımlayıcı faktör analizi (AFA)ve doğrulayıcı faktör analizi (DFA) ile incelenmiştir. Verilerin açımlayıcı faktör analizine uygunluğunun değerlendirilmesinde KaiserMeyer-Olkin (KMO) katsayısı ve Barlett küresellik testi kullanılmıştır. YYDÖ’de açıklanan toplam varyansın \%65,98 olduğu, birinci faktörün tek başına varyansın \%31,57'sini açıkladığ 1 ve maddelerin faktör yüklerinin birinci faktörde .40 ile .68 arasında değiştiği görülmektedir.

"Yaşam doyumu" bir insanın hayattan beklentileri ve bu beklentilerin ne kadar karşılandığının ölçütüdür (Özer ve Karabulut, 2003). Burada başkalarının kişiyi nasıl gördüğü dikkate alınmaz, kişinin kendisini nasıl algıladığı dikkate alınır (Diener, 1984, 1994; Pavot ve Diener, 1993; Pavot, Diener, Colvin ve Sandvik, 1991) Sonuç olarak öznel bir durumdur. Hayattan ne bekliyor ve neye sahip oluyor konusunun duygusal ve bilişsel iki bileşeni vardır. Duygusal bileşen, olumlu ve olumsuz duyguları içerir. Bilişsel bileşen ise yaşam doyumunu tanımlar. Düşünce düzeyinde bireyin hayattan beklentilerine ulaşıp ulaşamadığı ile ilgili doyumunu ifade eder.

Yetişkin yaşam doyumu ölçeği 5 alt boyuttan oluşmaktadır. Birinci faktör bireyin genel anlamda beklentilerine ulaşıp ulaşamadığını tanımlar ve genel yaşam doyumu olarak adlandırılır $(1,2,3$, 4, 5 ve 6. maddeler). Hayatımdan memnunum, hayat şartlarım mükemmel, hayatım çoğu arkadaşımın hayatından iyidir vb. sorulardan oluşmaktadır. İkinci faktör, ilişki doyumu $(7,8,9$, 10 ve 11. maddeler) olup, ailemle vakit geçirmeyi severim, yeterince arkadaşım var, ihtiyacım olduğunda arkadaşlarım bana yardımcı olurlar gibi maddelerden oluşmaktadır. Üçüncü faktör, benlik doyumu $(12,13,14$ ve 15 . maddeler) olup; eğlenceli birisiyim, kendimi seviyorum, iyi ve başarılı bir insanım gibi maddelerden oluşmaktadır. Dördüncü faktör, sosyal çevre doyumu (16, 17 ve 18. maddeler) olup; mahallemden memnunum, komşularımdan memnunum, yaşadığım yerde yapılabilecek eğlenceli birçok aktivite vardır maddelerinden oluşmaktadır. Beşinci faktör, iş doyumu (19, 20 ve 21. maddeler) olup; işimden memnununum, işe gitmek için sabırsızlanırım, hayata tekrar başlama şansı verilse aynı işi yaparım maddelerinden oluşmaktadır.

Stresle Başa Çıkma Yöntemleri Ölçeği; Moos (1993) tarafından geliştirilen Ballı ve Kılıç (2016) tarafindan Türkçeye uyarlanan "Stresle Başa Çıkma Yöntemleri Ölçeği”, mantıksal analiz, pozitif değerlendirme, profesyonel destek arama, problem çözme ve çevre desteği arama boyutlarından oluşmaktadır. Burada yetişkinlerin herhangi bir sorunla karşılaştıklarında soruna karşı nasıl yaklaştıkları üzerinde durulmuştur. 24 ifadeden oluşan ölçek 5'li Likert tipinde derecelendirilmiştir.

Yapılan analizler sonucunda çıkarılması gereken maddeler çıkarıldıktan sonra kalan 22 madde ve öz değeri 1'in üzerinde olan beş faktör toplam varyansın \%71,95'ini açıklamaktadır. Birinci faktör 6 maddeden oluşmakta ve toplam varyansın \%45,17'sini açıklamaktadır. Birinci faktör, $(6,20,21,22,23,24$. maddeler) problem çözme alt boyutu olup; insanların benden beklediklerini anlamaya çalışırım, yapılması gerekenleri ve ne istediğimi bilirim ne istediğime karar verip bunu gerçekleştirmek için çalışırım gibi maddeler içermektedir. 
İkinci alt boyut olan pozitif değerlendirme boyutu $(7,8,10,11,12$. maddeler) varyansın $\% 9,61$ 'ini açılamakta olup; kendimi daha iyi hissetmek için kendi kendimi motive ederim, benzer problemlere sahip insanlardan daha iyi durumda olduğumu düşünürüm, yaşadığım sorunların hayatımı olumlu olarak değiştireceğini düşünürüm gibi maddelerden oluşmaktadır.

Üçüncü faktör olan mantıksal analiz (1,2,3,4,5,19. maddeler) varyansın \%7,08'ini açıklamakta olup; sorunlarla başa çıkmak için farklı yollar düşünme, söylediklerimde ve yaptıklarımda aklımı izlerim, olaylardan ders almaya çalışırım gibi maddelerden oluşmaktadır.

Dördüncü faktör olan profesyonel destek arama faktörü, varyansın \%5,43'ünü açılamaktadır. Bu faktör 15. ve 16. maddeler olup; sorunlarla ilgili olarak profesyonel birinden yardım alırım, benzer problemler yaşamış kişi ya da gruplardan yardım alırım maddelerdir.

Beşinci faktör; olan çevre desteği arama, 13. ve 14. maddeler olup sorunlar hakkında eşim ya da diğer akrabalarımla konuşurum, sorunlar hakkında arkadaşımla konuşurum maddelerinden oluşturmaktadır. Bu faktör, varyansın \%4,67'sini açıklamaktadır.

Ölçeğin güvenirliğinin belirlenmesi için Cronbach Alpha analizi yapılmış ve güvenirlik katsayısı 0,93 bulunmuştur. $\mathrm{Bu}$ değer ölçeğin yüksek derecede güvenilir olduğunu göstermektedir.

\subsection{Araştırmanın örneklemi}

Örneklem grubumuzun \%67'i kadın, \%73'ü bekar kişilerden oluşmaktadır. İstanbul'u temsil edecek örneklem grubu İstanbul eğitim ortalamalarına göre oluşturulmuştur. TÜİK 2018 verilerine göre Endeksa firmasının oluşturduğu istatistiki verilere göre İstanbul Eğitim ortalamasını \%62,54 puan aralığındaki lise mezunları oluşturmaktadır. Çalışmamızda eğitim ortalamasını temsil eden semtler 3 ayrı grup olarak tanımlanmıştır. 1. grup eğitim ortalaması $\% 65$ 'in üzerindeki semtlerden, 2 . grup eğitim ortalamas $\% 55$ ile $\% 65$ arasındaki semtlerden ve 3.grup \%55 ve altındaki semtlerden oluşmaktadır.

Örneklem grubumuzu 1. Bölge olarak (Bakırköy, Beşiktaş, Beylikdüzü, Kadıköy, Şişli, Üsküdar, Ataşehir) toplam 160 kişi (\%37) oluşturmaktadır. 2. Bölgeden (Bahçelievler, Fatih, Küçükçekmece, Başakşsehir, Ümraniye, Güngören, Büyükçekmece, Sarıyer, Avcılar, Pendik, Beykoz, Kartal ve Çekmeköy)'den 169 kişi (\%39) ve 3. Bölgeden ise (Esenler, Sultangazi, Bağcılar, Gaziosman Paşa, Sancaktepe, Beyoğlu, Bayrampaşa, Esenyurt, Zeytinburnu, Kağıthane, Eyüp ve Maltepe)'den oluşan 103 kişi (\%24) oluşturmaktadır.

\section{4. İşlem}

Araştırmada kullanılan 3 ölçek basılmış bir şekilde hazırlanıp, sınıf, sokak, cafe, ev ortamında kişilere verilip uygulama yapıldıktan sonra toplanmıştır. Gerçekleştirilen çalışma toplamda 434 katılımcıya uygulanmış ve katılımcılardan alınan cevaplar SPSS 21.0 paket programı yardımı ile analiz edilmiştir. Cinsiyet, semt vb. demografik bilgilerin analiz edilmesi için verilere frekans analizi uygulanmıştır.

Bireylerin İstanbul'a ait sevdiği ve sevmediği özelliklerin madde puanı ortalamaları alınmıştır. Kullanılan ölçeklere verilen cevaplar arasında ilişkilere bakmak için ölçek toplam puanları ve alt boyut puanları arasında korelasyon analizi uygulanmıştır. Katılımcılar arasında cinsiyet ve medeni durum açısından farklılıklara bakmak için verilere bağımsız örneklem t-testi uygulanmıştır.

Katılımcıların İstanbul'u vazgeçilmez yapanın ne olduğu konusundaki görüşünü incelemek için ölçek toplam ve alt boyut puanları ile ekonomik, eğitim imkanları ve tarihi yer puanları arasında tek yönlü varyans analizi (Anova) uygulanmıştır. 


\section{BULGULAR}

Araştırmaya katılan katılımcılarımıza İstanbul'un özelliklerine ait 50 maddeden oluşan ve 5'li likert puanlamasına sahip bir ölçek verilmiştir. Katılımcıların 3 ve üstünde puan verdikleri özellikler İstanbul'a ait sevdiği özellikler, 3'ün altında puan verdikleri özellikler ise sevmediği özellikler olarak ayrılmıştır. Tablo 1'de katılımcıların İstanbul'a ait sevdiği özellikler ve ortalama puanları, Tablo 2'de ise sevmediği özellikler ve ortalama puanları verilmiştir.

Tablo 1: Ístanbul'da yaşayan bireylerin İstanbul'a ait sevdiği özellikler:

\begin{tabular}{|c|c|}
\hline Madde & Ort. \\
\hline $\begin{array}{l}\text { 1. Market, mağaza, manav, semt pazarı gibi alışveriş olanaklarından, yeterliliklerinden } \\
\text { uzaklıklarından... }\end{array}$ & 3.68 \\
\hline 2. Okul, üniversite, kurs gibi eğitim olanaklarından & 3.66 \\
\hline 3. Posta, kargo vb. hizmetlerden... & 3.53 \\
\hline 4. Banka hizmetlerinden... & 3.53 \\
\hline 5. Lokanta, kafe, kahvehane gibi halka açık yerlerin yeterliliğinden/uygunluğundan... & 3.46 \\
\hline 6. Telefon, elektrik, doğalgaz, internet gibi alt yapı hizmetlerinden... & 3.44 \\
\hline $\begin{array}{l}\text { 7. Hastane, sağlık ocağı, eczane gibi sağlık hizmeti olanak ve } \\
\text { yeterliliğinden/uygunluğundan... }\end{array}$ & 3.38 \\
\hline 8. Eğlence yerlerinden ve yeterliliğinden/uygunluğundan... & 3.36 \\
\hline $\begin{array}{l}\text { 9. Meyve, sebze, ekmek, süt gibi besin ürünlerine erişim/satın alma kolaylığı ve } \\
\text { kalitesinden... }\end{array}$ & 3.35 \\
\hline 10. Kültür, sanat ve benzeri etkinliklerin yeterliliğinden/uygunluğundan... & 3.33 \\
\hline 11. Kent esnafindan... & 3.32 \\
\hline 12. Cadde, sokak ve benzeri alanların aydınlatılmasından/uygunluğundan... & 3.32 \\
\hline $\begin{array}{l}\text { 13. Caddeler, sokaklar gibi halka açık alanların ve genel olarak kentin temizliğinden, çöp } \\
\text { toplama hizmetlerinden... }\end{array}$ & 3.29 \\
\hline 14. Ambulans hizmetlerinden... & 3.25 \\
\hline 15. İtfaiye hizmetlerinden... & 3.23 \\
\hline $\begin{array}{l}\text { 16. Şehirlerarası ulaşım olanakları ve otogar, havaalanı gibi hizmet alanlarına erişim } \\
\text { kolaylığından ... }\end{array}$ & 3.18 \\
\hline 17. Otobüs, minibüs, metro, taksi gibi kent içi ulaşım olanaklarından... & 3.16 \\
\hline 18. Düğün, nikah salonu gibi mekanların yeterliliğinden/uygunluğundan... & 3.13 \\
\hline 19. Kütüphane olanaklarından... & 3.12 \\
\hline 20. Mahalle sakinlerinden ve komşuluk ilişkilerinden... & 3.00 \\
\hline
\end{tabular}

Tablo 1'e bakıldığında katılımcıların genel olarak İstanbul şehrinin özelliklerine ortalama üstü ve birbirine yakın bir puan ortalamasına sahip olsa da en yüksek puan verilen ve beğenilen ilk üç özelliğin: market, mağaza, manav, semt pazarı gibi alışveriş olanakları, yeterlilikleri ve uzaklıkları; okul, üniversite, kurs gibi eğitim olanakları; posta, kargo vb. hizmetleri olduğu görülmektedir.

Tablo 2: İstanbul'da yaşayan bireylerin İstanbul'a ait memnun olmadı̆̆ özellikler: 


\begin{tabular}{|c|c|}
\hline Madde & Ort. \\
\hline 1. Gürültü kirliliğinden... & 1.88 \\
\hline 2. Kentteki ev satış ve kira fiyatlarından... & 1.91 \\
\hline 3. Kent içindeki insan yoğunluğundan, kalabalıktan... & 1.93 \\
\hline 4. Kent havasının temizliğinden... & 2.03 \\
\hline 5. Çevrenin ve doğal hayatın korunmasından... & 2.17 \\
\hline 6. İmar planlaması gibi şehir planlama ve uygulamalarından... & 2.25 \\
\hline $\begin{array}{l}\text { 7. Kent insanının genel ahlak ve sosyal kurallara uyma gibi birlikte yaşama alışkanlıklarından, } \\
\text { tutumlarından... }\end{array}$ & 2.26 \\
\hline 8. Kent içi trafikten, sinyalizasyon ve diğer trafik hizmetlerinden... & 2.32 \\
\hline 9. Çocuklar için uygun oyun alanların yeterliliğinden/uygunluğundan... & 2.41 \\
\hline 10. Yeşil alan, park gibi mekanların yeterliliğinden/uygunluğundan... & 2.47 \\
\hline 11. Başkaları tarafindan rahatsız edilmeden özgürce yaşayabilme olanaklarından... & 2.49 \\
\hline 12. Otopark olanaklarından... & 2.51 \\
\hline 13. Kaldırımların genişliğinden, yürüyüş için uygunluğundan... & 2.53 \\
\hline 14. Kent güvenliği ve düzeninden... & 2.57 \\
\hline 15. İçme suyu şebekesinden ve temizliğinden... & 2.60 \\
\hline 16. Spor salonu, stadyum, havuz gibi spor tesislerinin & 2.62 \\
\hline 17. Yürüme, koşma gibi spor yapma olanaklarından/uygunluğundan... & 2.64 \\
\hline 18. Kentteki iş olanaklarından... & 2.69 \\
\hline 19. Kent gelişiminden, kalkınma düzeyinden... & 2.70 \\
\hline 20. Kanalizasyon, yağmur suyu tahliye sisteminden... & 2.72 \\
\hline 21. Zabita hizmetlerinden... & 2.76 \\
\hline 22. Kedi, köpek gibi sokak hayvanlarının sayısından/durumundan... & 2.76 \\
\hline $\begin{array}{l}\text { 23. Tapu ve kadastro müdürlüğü, vergi dairesi, nüfus vatandaşlık işleri, adli hizmetler vb. diğer } \\
\text { kamu hizmetlerinden... }\end{array}$ & 2.76 \\
\hline 24. Lokanta, kafe, büfe türü yiyecek ve içecek satılan yerlerin temizliğinden, hijyeninden... & 2.77 \\
\hline 25. Çevresel faktörlerden, bölge ikliminden... & 2.83 \\
\hline 26. Muhtarlık ve diğer mahalli hizmetlerden... & 2.84 \\
\hline 27. Kurban kesimi ve veterinerlik hizmetlerinin yeterliliğinden/uygunluğundan... & 2.85 \\
\hline 28. Kavşak, köprü gibi yol yapım ve bakım hizmetlerinden... & 2.88 \\
\hline 29. Engelli, yaşlı, fakir gibi ihtiyaç sahiplerine yönelik sosyal yardım hizmetlerinden... & 2.96 \\
\hline 30. Mezarlıklardan ve defin hizmeti yeterliliğinden/uygunluğundan... & 2.97 \\
\hline
\end{tabular}

Tablo 2'ye bakıldığında katılımcıların kent yaşamında genel olarak, kent içerisindeki gürülttü, çevre, hava kirliliğinden, kent yaşamını içerisinde doğal yaşamın ve spor olanaklarının az olmasından ve uyumlu yaşama problemlerinden şikâyet ettiklerini görebiliyoruz. Yine de kent yaşamı içerisinde memnun olunmayan ilk üç özellik: gürültü kirliliği; kentteki ev satış ve kira fiyatları, kent içindeki insan yoğunluğu, kalabalığı olduğu görülmektedir. 
Tablo 3: Kullanılan Ölçeklerin Birbirleriyle Korelasyon Katsayıları

\begin{tabular}{ccccccccccccccc}
\hline Ölçekler & & 1 & 2 & 3 & 4 & 5 & 6 & 7 & 8 & 9 & 10 & 11 & 12 & 13 \\
\hline
\end{tabular}

1. A Kent Yaşamından

Memnuniyet Ölçeği (A-KYMÖ- $p$

50) Toplam Puanı

$\mathrm{n}$

r, 330

2. Yetişkin Yaşam Doyumu

Ölçeği Toplam Puanı

p ,000

n 434

3. Yetişkin Yaşam Doyumu

r ,299,783

Ölçeği Genel Yaşam Doyumu

Alt Boyutu Toplam Puanı

p ,000,000

n 434434

4.Yetişkin Yaşam Doyumu

Ölçeği İlişki Doyumu Alt

r ,167,717,412

Boyutu Toplam Puanı

p ,000,000,000

n $434 \quad 434 \quad 434$

5. Yetişkin Yaşam Doyumu

Ölçeği Benlik Doyumu Alt

Boyutu Toplam Puanı

r , 109, 737, 443

p ,024,000,000,000

n $434 \quad 434 \quad 434 \quad 434$

r ,366, 607, 372, 232,

6. Yetişkin Yaşam Doyumu Ölçeği Sosyal Çevre Doyumu Alt Boyutu Toplam Puanı

p 000,000 000, 000, 000,

n $434 \quad 434 \quad 434 \quad 434 \quad 434$

r ,247,642, 417, 246 293

7. Yetişkin Yaşam Doyumu

Ölçeği İş Doyumu Alt Boyutu

Toplam Puanı

p 000,000, 000, 000, 000,

$\begin{array}{lllllll}\text { n } & 427 & 427 & 427 & 427 & 427 & 427\end{array}$

8. Stresle Başa Çıkma

r 238, 468, 259, 329, 328, 412,

Yöntemleri Ölçeği Toplam

p 000,000 000, 000, 000, 000, 000,

Puan1

n $434 \quad 434 \quad 434 \quad 434 \quad 434 \quad 434 \quad 427$

9. Stresle Başa Çıkma

r 216, 888

Yöntemleri Ölçeği Problem

Çözme Alt Boyutu Toplam

Puanı

p 000,000 000, 000, 000, 000, 000,

n $4 \begin{array}{llllllll}433 & 433 & 433 & 433 & 433 & 433 & 426 & 433\end{array}$

r 217 707, 835, 320, 300, 335, 386, 205,

10. Stresle Başa Çıkma

Yöntemleri Ölçeği Pozitif

Değerlendirme Alt Boyutu

Toplam Puanı

p 000 000, 000, 000, 000, 000, 000, 000,

$\begin{array}{llllllllll}\text { n } & 434 & 434 & 434 & 434 & 434 & 434 & 427 & 434 & 433\end{array}$

11. Stresle Başa Çıkma

r , 189, 669, 889, 328, 232, 280, 351, 350, 230,

Yöntemleri Ölçeği Mantıksal Analiz Ölçeği Alt Boyutu Toplam Puanı

p 000 000, 000, 000, 000, 000, 000, 000, 000,

n $4334 \quad 434 \quad 434 \quad 434 \quad 434 \quad 434 \quad 427 \quad 434 \quad 433 \quad 434$

r , 539, 508, 599, 289, 260, 262, 192, 194, 136, 237,

12. Stresle Başa Çıkma

p 000 000, 000, 000, 000, 000, 000, 000, 000, 000, 
Toplam Puanı

13. Stresle Başa Çıkma Yöntemleri Ölçeği Çevre Desteği Arama Alt Boyutu Toplam Puanı

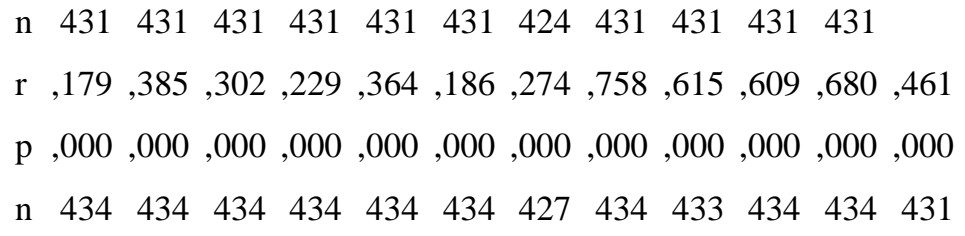

Yukarıda görülen korelasyon sonuçlarına göre kent memnuniyeti ile yaşam doyumu ve stresle başa çıkma yöntemleri arasında $\mathrm{p}<0.000$ düzeyinde anlamlı bir ilişki bulunmuştur. Yetişkin yaşam doyumu ile stresle başa çıkma konusunda profesyonel destek alma konusunda $\mathrm{p}<0.005$ düzeyinde farklılık bulunmuştur.

Aynı zamanda stresle başa çıkma yöntemlerinin alt boyutlarından problem çözme ile pozitif değerlendirme, mantıksal analiz, profesyonel destek ve çevre desteği arama arasında $p<0.000$ düzeyinde pozitif bir ilişki bulunmuştur.

Yaş Grupları için Tek Yönlü Varyans Analizi Sonuçları (serbestlik derecesi $(2,431)$ )'nda anlamlı bir ilişki bulunmamıştır. Bu durum çalışmamızın örnekleminde yaş farklılıklarının kent memnuniyeti, yaşam doyumu ve stresle baş etme konusunda bir farklılık oluşturmadığını göstermektedir.

Tablo 4: Cinsiyet İ̧̧in Farklı Gruplar İçin T-Testi Analizi Sonucu

\begin{tabular}{llllr}
\hline \multicolumn{1}{c}{ Toplam Puan } & Cinsiyet & N & Ort. & SS \\
\hline Yetişkin Yaşam Doyumu Ölçeği Toplam Puanı & kadın & 289 & 77,32 & 11,789 \\
& erkek & 145 & 74,03 & 14,066 \\
Yetişkin Yaşam Doyumu Ölçeği İlişki Doyumu Alt Boyutu & kadın & 289 & 21,64 & 3,324 \\
Toplam Puanı & erkek & 145 & 20,01 & 4,520 \\
Yetişkin Yaşam Doyumu Ölçeği Benlik Doyumu Alt Boyutu & kadın & 289 & 16,62 & 2,860 \\
Toplam Puanı & erkek & 145 & 15,64 & 3,607 \\
\hline
\end{tabular}

Araştırmaya katılan farklı cinsiyetteki katılımcılar arasında ölçek puanları açısından bir fark olup, olmadığını anlamak için bağımsız örneklem t-testi uygulandı. Tablo 4'e bakıldığında cinsiyet için bağımsız örneklem t-testi analizi sonucunda kent memnuniyeti ve stresle baş etme konusunda bir farklılık çıkmaz iken yaşam doyumu açısından farklılık bulgusuna rastlanmıştır.

Tablo 5: Toplam Puan ve Alt Boyutlar Arası Kolerasyon

\begin{tabular}{|c|c|}
\hline Ölçek & SD \\
\hline Yetişkin Yaşam Doyumu Ölçeği Toplam Puanı & 432,011 \\
\hline Yetişkin Yaşam Doyumu Ölçeği İlişki Doyumu Alt Boyutu Toplam Puanı & $3,843224,496,000$ \\
\hline Yetişkin Yaşam Doyumu Ölçeği Benlik Doyumu Alt Boyutu Toplam Puanı & $2,857237,378,005$ \\
\hline
\end{tabular}

Yaşam doyumu için kadın ve erkek arasındaki farklılığı incelediğimizde kadınların lehine ilişki ve benlik doyumu alt boyutları açışından anlamlı bir fark bulunmuştur. $\mathrm{Bu}$ durum kadınların hayattan daha fazla keyif aldığı, ilişki ve benlik algısı konusunda kendilerini daha fazla 
geliştirdiğini de düşündürebilir veya ekonomik zorluklarla baş etme erkeklerin daha fazla omuzunda olması ile de açıklanabilir.

Tablo 6: Medeni Durum İ̧̧in Farklı Gruplar İçin T-Testi Analizi Sonucu

\begin{tabular}{lllll}
\hline & Medeni durum & n & Ort. & s \\
\hline Yetişkin Yaşam Doyumu Ölçeği Toplam Puanı & bekar & 31775,25 & 12,719 \\
& evli & 11578,79 & 12,212 \\
Yetişkin Yaşam Doyumu Ölçeği Sosyal Çevre Doyumu Alt & bekar & 317 & 9,48 & 3,210 \\
Boyutu Toplam Puanı & evli & 11510,10 & 2,637 \\
\hline
\end{tabular}

Tablo 7: Medeni Durum İçin Farklı Gruplar İçin T-Testi Analizi Sonucu

\begin{tabular}{|c|c|c|c|}
\hline & $\mathbf{t}$ & sd & $\mathbf{p}$ \\
\hline Yetişkin Yaşam Doyumu Ölçeği Toplam Puanı & $-2,585$ & 430 & ,010 \\
\hline $\begin{array}{l}\text { Yetişkin Yaşam Doyumu Ölçeği Sosyal Çevre Doyumu Alt Boyutu } \\
\text { Toplam Puanı }\end{array}$ & $-2,039$ & 244,025 & ,043 \\
\hline
\end{tabular}

Katılımcıların ölçek puanlarını medeni durum açısından değerlendirmek için bağımsız örneklem t-testi uyguladığımızda gruplar arasında çok anlamlı bir farklılık çıkmasa da bekar katılımcılar, evli olan katılımc1lara oranla daha düşük puan sahiptirler ( $p>0.005)$.

Tablo 6 ve tablo 7'ye bakıldığında t değeri evli olanların puan ortalaması, bekarlardan puan ortalamasından daha yüksektir. Bir başka ifade ile evli grup bekar gruba göre yaşam doyumu ve sosyal çevre doyumu açısından daha yüksek ortalamaya sahiptir. Yaşam doyumu konusunda yapılan çalışmalarla paralellik göstermektedir. Sosyal çevreden mahalle ve komşularla ilişkilerden memnun olmak; genel yaşam doyumunda da hayatımı düzene koydum, hayatım arkadaşlarıma göre iyidir cevapları toplumun beklentilerine ulaşmış evli insanların daha memnun olması beklenebilir. 
Tablo 8: İstanbul'u Vazgeçilmez Yapanın Ne Olduğu Konusundaki Görüş İçin Tek Yönlü Varyans Analizi Sonuçları (Serbestlik Derecesi $(3,424)$ )

\begin{tabular}{|c|c|c|c|}
\hline $\begin{array}{l}\text { İstanbul'u vazgeçilmez yapanın ne olduğu konusundaki } \\
\text { görüş̧ }\end{array}$ & & N Ort. & $\mathbf{S}$ \\
\hline \multirow{5}{*}{$\begin{array}{l}\text { A Kent Yaşamından Memnuniyet Ölçeği (A-KYMÖ-50) } \\
\text { Toplam Puanı }\end{array}$} & Ekonomik imkanlar & 8952,14 & $\overline{13,836}$ \\
\hline & Eğitim imkanları & 6655,27 & 13,293 \\
\hline & Tarihi yerler & 4756,68 & 13,034 \\
\hline & Hepsi & 22360,21 & 13,009 \\
\hline & Toplam & 42557,37 & 13,586 \\
\hline \multirow[t]{5}{*}{ Yetişkin Yaşam Doyumu Ölçeği Toplam Puanı } & Ekonomik imkanlar & 8972,65 & 11,568 \\
\hline & Eğitim imkanları & 6675,80 & 12,876 \\
\hline & Tarihi yerler & 4775,74 & 13,134 \\
\hline & Hepsi & 22377,90 & 12,710 \\
\hline & Toplam & 42576,24 & 12,677 \\
\hline \multirow{4}{*}{$\begin{array}{l}\text { Yetişkin Yaşam Doyumu Ölçeği Genel Yaşam Doyumu Alt } \\
\text { Boyutu Toplam Puanı }\end{array}$} & Ekonomik imkanlar & 8919,02 & 4,243 \\
\hline & Eğitim imkanları & 6620,33 & 4,545 \\
\hline & Tarihi yerler & 4719,98 & 4,311 \\
\hline & Toplam & 42520,08 & 4,404 \\
\hline \multirow{5}{*}{$\begin{array}{l}\text { Yetişkin Yaşam Doyumu Ölçeği Sosyal Çevre Doyumu Alt } \\
\text { Boyutu Toplam Puanı }\end{array}$} & Ekonomik imkanlar & 899,25 & 3,005 \\
\hline & Eğitim imkanları & 668,73 & 3,121 \\
\hline & Tarihi yerler & 4710,04 & 2,963 \\
\hline & Hepsi & 22310,04 & 3,011 \\
\hline & Toplam & 4259,67 & 3,054 \\
\hline \multirow{5}{*}{$\begin{array}{l}\text { Yetişkin Yaşam Doyumu Ölçeği İ ş Doyumu Alt Boyutu } \\
\text { Toplam Puanı }\end{array}$} & Ekonomik imkanlar & $88 \quad 8,48$ & 3,262 \\
\hline & Eğitim imkanları & 669,56 & 3,688 \\
\hline & Tarihi yerler & $47 \quad 8,62$ & 3,398 \\
\hline & Hepsi & 2179,67 & 3,386 \\
\hline & Toplam & 4189,28 & 3,439 \\
\hline \multirow[t]{5}{*}{ Stresle Başa Çıkma Yöntemleri Ölçeği Toplam Puanı } & Ekonomik imkanlar & 8987,88 & 14,021 \\
\hline & Eğitim imkanları & 6693,53 & 13,474 \\
\hline & Tarihi yerler & 4791,26 & 13,996 \\
\hline & Hepsi & 22393,53 & 13,556 \\
\hline & Toplam & 42592,09 & 13,832 \\
\hline \multirow{5}{*}{$\begin{array}{l}\text { Stresle Başa Çıkma Yöntemleri Ölçeği Problem Çözme Alt } \\
\text { Boyutu Toplam Puanı }\end{array}$} & Ekonomik imkanlar & 8821,51 & 3,655 \\
\hline & Eğitim imkanları & 6622,73 & 3,889 \\
\hline & Tarihi yerler & 4722,09 & 4,353 \\
\hline & Hepsi & 22322,91 & 3,798 \\
\hline & Toplam & 42422,50 & 3,876 \\
\hline
\end{tabular}




\begin{tabular}{|c|c|c|c|}
\hline \multirow[t]{5}{*}{$\begin{array}{l}\text { Stresle Başa Çıkma Yöntemleri Ölçeği Pozitif Değerlendirme } \\
\text { Alt Boyutu Toplam Puanı }\end{array}$} & ekonomik imkanlar & 8922,08 & 3,635 \\
\hline & eğitim imkanları & 6623,55 & 3,505 \\
\hline & tarihi yerler & 4723,64 & 3,703 \\
\hline & hepsi & 22323,67 & 3,747 \\
\hline & Toplam & 42523,32 & 3,725 \\
\hline
\end{tabular}

Katılımcıların İstanbul'u vazgeçilmez yapanın ne olduğu konusundaki görüşleri ile ölçek puanları arasındaki tek yönlü varyans analizi sonuçlarına baktığımızda, bireylerin stresle başa çıkma konusunda özellikle eğitim imkanlarının önemli bir rol oynadığını görebiliyoruz. Bunu sırasıyla tarihi yerler ve ekonomik imkanlar izliyor. Ama katılımcıların yaşam doyumu ölçeğinin alt boyutlarından iş doyumu ve sosyal doyum açısından ekonomik, eğitim imkanlarını ve tarihi yerleri düşük değerlendirdiğini söyleyebiliriz.

Tablo 9: İstanbul'u Vazgeçilmez Yapanın Ne Olduğu Konusundaki Görüşşçin Tek Yönlü Varyans Analizi Sonuçları

\begin{tabular}{lc}
\hline & F \\
\hline A Kent Yaşamından Memnuniyet Ölçeği (A-KYMÖ-50) Toplam Puanı & $8,656,000$ \\
Yetişkin Yaşam Doyumu Ölçeği Toplam Puanı & $3,777,011$ \\
Yetişkin Yaşam Doyumu Ölçeği Sosyal Çevre Doyumu Alt Boyutu Toplam Puanı & $4,077,007$ \\
Yetişkin Yaşam Doyumu Ölçeği İş Doyumu Alt Boyutu Toplam Puanı & $3,302,020$ \\
Stresle Başa Çıkma Yöntemleri Ölçeği Toplam Puanı & $3,933,009$ \\
Stresle Başa Çıkma Yöntemleri Ölçeği Problem Çözme Alt Boyutu Toplam Puanı & $3,040,029$ \\
Stresle Başa Çıkma Yöntemleri Ölçeği Pozitif Değerlendirme Alt Boyutu Toplam Puanı & $4,252,006$ \\
\hline
\end{tabular}

Kent memnuniyeti açısından değerlendirdiğimizde tarihi, eğitim, ekonomik önemli görülen İstanbul, ikinci sırada tarihi özellikleri ile tanımlanmaktadır. Bu durum İstanbul'un ekonomik imkanlarından İstanbul'un tercih edildiği görüşü ile farklılık oluşturmaktadır. Bu durumu eğitim imkanları takip etmektedir. Örneklem grubumuz tarafindan, İstanbul eğitim ve tarihsel bir şehir algilanmaktadir.

Yaşam doyumu açısından ve stresle başa çıkma açısından bakıldığında ise eğitim imkanları için seçenlerin ortalamaları anlamlı derecede yüksektir.

Kullanılan toplu taşıma ile kent memnuniyeti, yaşam doyumu ve stresle başa çıkma açısından bir farklılık görülmemiştir.

\section{SONUÇ}

Kent memnuniyeti açısından bakıldığında İstanbul, örneklem grubumuz tarafindan, temel ihtiyaçların karşılanabildiği bir şehir olarak algılanmaktadır. Bu durumu ön sıralara market, mağaza gibi ihtiyaçlarını karşılayabildikleri yerleri koymalarından anlayabiliriz. İstanbul'da son yıllarda artan alışveriş merkezlerinin, bireylerin İstanbul'a dair algısını alışveriş şehri olarak değiştirdiğini söyleyebiliriz. 
Katılımcıların, ihtiyaçların karşılanabildiği bir şehir algısını, eğitim olanakları olan bir şehir algısı takip etmektedir. Bu durumu bireylerin İstanbul'a dair olan algılarının, İstanbul'u bir eğitim şehiri olarak gördükleri şeklinde yorumlayabiliriz. Banka, postane, lokanta, hastane hizmetleri ve eğlence yerleri ile devam eden memnuniyet sıralamasında kültür, sanat etkinliklerinin 10. sirada yer alması dikkat çekmektedir. İstanbul, eğitim kurumları açısından sayıca artmakla beraber kültürel etkinlik açısından geride kalması eğitimin niceliksel olarak artmasına rağmen niteliksel artı̧̧1 konusunda sorgulanmaya ihtiyaç olduğunu göstermektedir. Katılımcıların, eğitim kurumlarına dair daha iyi bir algıları olmasına ragmen, kültürel etkinliklere dair algılarının düşük olması, bu özelliklerin eşdeğer bir şekilde artmadığını düşündürmektedir. Eğitim kurumları ile açılan alışveriş merkezi, kafe ve restaurant gibi yerlerin arttı̆̆ını ancak kültürel etkinliklerin yapıldığ 1 yerlerde bir değişim olmadığı şeklinde yorumlayabiliriz. Aynı şekilde kütüphane memnuniyetinin 19. sirada yer alması bu durumu teyit eder niteliktedir. Yinede bu sayıların nicel bir araştırma yapılarak karşılaştııılması, bu konu hakkında daha somut bilgiler edinmemizi sağlayacaktır.

İstanbul'da memnun olunmayan bulgulara baktığımızda ilk sırada gürültü kirliliği yer almaktadır. $\mathrm{Bu}$ durumu ev, kira fiyatlarının fazlalığı, insan yoğunluğu, hava kirliliği, doğal hayatın korunamadığı, çarpık kentleşme, insanların bir arada yaşama konusundaki kurallara uymamasının zorlukları, trafik, çocuklara ait oyun alanları ve yeşil alanın azlığı izlemektedir. Araştirmamiza katılan bireylerin bu ifadesi, hızla artan nüfusa sahip olan İstanbul'un niteliksel açısından ise hızla düştüğünü açıkça göstermektedir. Trafik sorunun 8. sırada yer alması ise toplu taşıma araçlarına yapılan yatırımların sonuç verdiğini ama yeterli olmadığını göstermektedir. Aynı zamanda memnuniyeti arttırmaya yönelik olarak yapılan gökdelenlerin, problemleri çözemediği ve hatta gürültü, ev fiyatları, hava kirliliği ve doğal hayatın ihlal edilmesi gibi problemlerin ön plana çıkmasına sebep olduğunu düşündürmektedir.

İstanbul'da memnun olunan ve olunmayan özellikleri birlikte incelediğimizde, İstanbul'a dair bireylerin algıladığı memnun olunan özelliklerin, İstanbul'un küreselleşmesini ve gökdelen tarzı yapıların hızlı bir şekilde yapılaşmayı arttırdığı şeklinde yorumlayabiliriz. Ancak bu durum, İstanbul'a dair memnun olunmayan özelliklerin artmasına sebep olduğu şeklinde yorumlanabilir. Aynı şekilde, bu durum hızlı yapılaşma ve artan göç sonucu, şehir nüfusunun, gürültü ve hava kirliliğini arttı̆̆ ve yine doğal alanlara zarar vermesi ile açıklanabilir. Ev kiralarının ve fiyatlarının yüksek olması, artan gökdelen ve yapılaşmanın İstanbul'a dair memnuniyeti arttırmadığını şeklinde yorumlanabilir.

Bunun yanında hızla artan nüfusa karşın alt yapı ve banka, postane hizmetlerinden memnun olunması yerel yönetimlerin bu konuda etkili çalıştığını düşündürmektedir. Bunun yanı sıra güvenlik, kalabalık, kültürel etkinlik, yeşil alan imar planının memnun olunmayan özellikler açısından ön sıralarda ifade edilmesi, insani ve sosyal özellikler açısından yaşamanın zorluklarına dikkat çekmektedir.

Yaşam doyumu açısından bulguları değerlendirdiğimizde eğitim imkanlarının genel yaşam doyumu ile pozitif yönde ilişkisi olduğunu görmekteyiz. Bu durum İstanbul'da kiş̧ilerin eğitim olanakları açısından İstanbul'u olumlu algıladıklarını göstermektedir. Ayrıca, evli grubun, bekar gruba göre yaşam memnuniyeti nispeten daha yüksektir. Evli bireylerin daha yüksek sosyal çevre memnuniyetine sahip olması, evli olmanın şehirde yaşamak açısından, memnuniyet arttırıcı bir etkiye sahip olduğunu düşündürmektedir. Burada bekar hayatının memnuniyette düşük çıkması üniversite öğrencileri açısından dezavantajlı bir durum olarak düşünülebilir. Bu durum, bekar olan bireylerin, güvenlik açısından kendisini daha az güvende hissetmesi ile ilgili olarak açılanabilir. Sanat, kültür ve yeşil alan, park memnuniyetinin onuncu sırada olması ev dışına doğru değil, ev içine doğru hayatın yaşandığını düşündürmektedir.

Stres açısından bakıldığında ise; kent memnuniyeti ve yaşam doyumu açısından yüksek düzeyde ilişki bulunmuştur. İstanbul'un memnun olunmayan özelliklerinin dikkate alınmasının bu şehirde yaşayanların stress ve yaşam doyumunu da olumlu yönde değiştireceği düşünülebilir. Bunun 
yanında eğitim olanakları ile stresle başa çıkma arasında yüksek düzeyde ilişki çıkması eğitimin stresle başa çıkma konusunda önemli bir unsur olduğuna dikkat çekmektedir.

İstanbul'u vazgeçilmez yapan nedir sorusuna hepsi seçeneği dışında, tarihi mekanların birinci sırada yer alması dikkat çekicidir. Bu durumu eğitim imkanları ve ekonomik imkanlar takip etmektedir. Bu sıralama, İstanbul'da yaşayan bireylerin, İstanbul'u artık taşı toprağı altın şehir olarak algılamadığını düşündürmektedir. Bu durum İstanbul'un tarihi özelliğinin, eğitim ve ekonomik özelliklerinden daha fazla tercih edildiğini fakat tarihi özelliklerinin vazgeçilmez olarak tanımladığını göstermektedir. Yüksek binalar arasında kalan tarihi görünüm hala katılımcılar açısından İstanbul'u tanımlayan bir simge olarak ifade edilmektedir.

Sonuç olarak katılımcılarımız tarafından, İstanbul Bookchin'in (1999) tanımında ifade ettiği gibi kentsiz kentlileşme olgusu ile karşı karşıyadır. Geleneksel yaşamın, kentli yaşamın önüne geçtiğini düşünülmektedir. Kent memnuniyeti ile yaşam ve stres yönetimi açısından kuvvetli bir ilişki bulunmuştur. Bu durum, bireylerin İstanbul'dan memnun oldukları şehir olması durumunda İstanbul'un yaşamdan zevk alan ve stresle başa çıabilen bir nüfusa sahip olabileceğini düşündürmektedir.

Çalışmadan elde ettiğimiz veriler 1şığında, şehir bağlılığı konusunda araştırma yapılma önerisi yanında, yerel yönetimlerin şehrin tarihi dokusunu korumaya, kültürel etkinlikleri arttırmaya yönelik çalışmalara öncelik vermeleri önerilebilir. 


\section{Kaynakça}

Ballı, A, Kılıç, K. (2016). Stresle Başa Çıkma Yöntemleri Ölçeğinin Türkçe'ye Uyarlanması: Geçerlilik Ve Güvenirlik Çalışması. Çukurova Üniversitesi Sosyal Bilimler Enstitüsü Dergisi, 25 (3), ss.273-286.

Baltaş Z, Baltaş A. (2012). Stres ve Başa çıkma Yolları. 29. Basım. İstanbul: Remzi Kitabevi. 2012, ss.72-73.

Bell, P. A., Fisher, J. D., \& Loomis, R. J. (1978). Environmental psychology. Philadelphia: Saunder Company.

Benevolo, L., \& Nirven, N. (1995). Avrupa tarihinde kentler. İstanbul: AFA Yayınları.

Berkowitz, L. (1989). Frustration-aggression hypothesis: Examination and reformulation, Psychological Bulletin,106(1), 59-73. doi:10.1037//0033-2909.106.1.59

Bilgin, N. (2011). Sosyal Düşüncede Kent Kimliği, İdeal Kent Dergi (3), ss.20-47.

Bookchin, M. (1999) Kentsiz Kentleşme: Yurttaşlı̆̆ın Yükselişi ve Çöküşü. Çev. Burak Özyalçın, İstanbul:Ayrıntı, s.9-39.

Çizgen, N (1994), Kent Ve Kültür. İstanbul: Say Yayınları.

Diener, E. (1984). Subjective well-being. Psychological Bulletin, 95, ss.542- 575.

Diener, E. (1994). Assessing subjective well-being: Progress and oppurtunities. Social Indicators Research, 31, ss.103-157.

Diener, E., Oishi, S., \& Lucas, R. E. (2003). Personality, Culture, and Subjective Well-Being: Emotional and Cognitive Evaluations of Life. Annual Review of Psychology,54(1), ss.403-425. doi:10.1146/annurev.psych.54.101601.145056

Duru, B. (2001) Gökdelenler ve Kent. Ankara: Mülkiyeliler Birliği Yayınları, s.331-362.

Dyce, James M. (1973). Stres and Decision-Making in Dental Practice. Berlin ve Chicago: Quintessence Books.

Engez, A. (2007) Küreselleşme Sürecinde Kentlerin İmaj ve Kimlikleri: Karşılaştırmalı İstanbul Örneği, Marmara Üniversitesi Sosyal Bilimler Enstitüsü, Yayınlanmamış Yüksek Lisans Tezi.

Hançerlioğlu, O., (2002). Felsefe Sözlüğü. İstanbul: Remzi Kitabevi

İstanbul. (n.d.). Retrieved from https://tr.wikipedia.org/wiki/İstanbul\#Nüfus yapıs1

Kaba, İ, Erol, M, Güç, K. (2018). Yetişkin Yaşam Doyumu Ölçeğinin Geliştirilmesi. Anadolu Üniversitesi Sosyal Bilimler Dergisi, 18 (1), ss.1-14. DOI: 10.18037/ausbd.550232

Kamp, I. V., Leidelmeijer, K., Marsman, G., \& Hollander, A. D. (2003). Urban environmental quality and human well-being. Landscape and Urban Planning,65(1-2), ss.5-18. doi:10.1016/s0169-2046(02)00232-3

Kaypak, Ş. (2013), Küreselleşme Sürecinde Kentlerin Markalaşması Ve "Marka Kentler", C. $\ddot{U}$. Íktisadi ve İdari Bilimler Dergisi, 14, (1), ss.335-355

Lalli, M. (1992). Urban-related identity: Theory, measurement, and empirical findings. Journal of Environmental Psychology, 12(4), 285-303. doi:10.1016/s0272-4944(05)80078-7

Lazarus, R. S., \& Folkman, S. (1984). Stress, appraisal, and coping. New York: Springer.

Liu, B.C. (1976). Quality of Life Indicators in US Metropolitan Areas: A Statistical Analysis. New York: Praeger Publishers,. 
Lynch, K. (1996). Çevrenin İmgesi. çev. (İlknur Özdemir), Cogito, 8, ss.153-161.

Moos, R. H. (1993). Coping Responses Inventory: Professional manual. Odessa, FL: Psychological Assessment Resources.

National Research Council (2002). Community and Quality of Life: Data Needs for Informed Decision Making. Washington DC: National Academy Press.

Özer, M., \& Karabulut, Ö. (2003). Yaşlılarda Yaşam Doyumu. Turkish Journal of Geriatrics,6(2), ss.72-74.

Pavot, W.G., Diener, E., Colvin, C.R. and Sandvik, E. (1991) Further Validation of the Satisfaction with Life Scale: Evidence for the Cross-Method Convergence of Well-Being Measures. Journal of Personality Assess, 57, ss.149-161. http://dx.doi.org/10.1207/s15327752jpa5701_17

Pavot, William \& Diener, Ed. (1993). Review of the Satisfaction With Life Scale. Psychological Assessment. (5), ss.164-172. doi:10.1037/1040-3590.5.2.164.

Pavot, W., \& Diener, E. (2004). The subjective evaluation of well-being in adulthood: Findings and implications. Ageing International, 29(2), ss.113-135. doi:10.1007/s12126-004-10134

Proshansky, H. M. (1978). The City and Self-Identity. Environment and Behavior,10(2), ss.147169. doi:10.1177/0013916578102002

Rapoport, A. (1977). Human Aspects of Urban Form, Oxford: Pergamon Press.

Sabuncuoğlu, Z., \& Tüz, M. V. (1998). Örgütsel psikoloji. İstanbul: Alfa Yayınları.

Selye, H. (1956). The stress of life. New York, NY, US: McGraw-Hill.

Simmel, G. (1993). The Metropolis and Mental Life. In D. N. Levine (Ed.), Georg Simmel on individuality and social forms: Selected writings. Chicago: The University of Chicago Press.

Tatar, A, Özüdoğru, M, Uysal, A, Uyğur, G . (2017). A Kent Yaşamından Memnuniyet Ölçeği'nin Geliştirilmesi ve Psikometrik Özelliklerinin İncelenmesi. Kent Akademisi, 10 (32), ss.413-431.

Tatlıdil, E, (1994). Kent Kültürü ve Boş Zaman Değerlendirme. Ankara: Sosyoloji Derneği Yayınları.

Van Kamp, L., Leidelmeijer, K., Marsman, A., Hollander, A. (2003). Urban environmental quality and human well-being, towards a conceptual framework and demarcation of concepts; a literature study. Landscape and Urban Planning, 65, ss.5-18.

WIRTH, L. (2002). Bir Yaşama Biçimi Olarak Kentleşme, 20. Yüzyıl Kenti. Haz. ve Çev. Bülent Duru ve Ayten Alkan, İstanbul: İmge Yayınevi. 